\title{
More change for British research
}

The proposed amalgamation of the British research councils (another reorganization, and suspect on that account) deserves a welcome if its management can satisfy some obvious tests.

WHAT will happen next to the British research enterprise? That must have been the question on the minds of members of the Academia Europaea at their second meeting in London this week (see page 651). Mr Kenneth Baker, Secretary of State for Education and Science, is the nearest thing to a minister of science that the British allow themselves (but he must worry about schools and what is taught in them as well). He is also a good minister, one whose avuncular appearence is matched by avuncular inclinations, and who is also the means by which an extra $£ 100$ million has been added to the British science budget this year. On Monday, he outlined for a European audience a seamless rationalization of British government policy on research that made the events of the past ten years appear both logical and predetermined. But $\mathrm{Mr}$ Baker also made it clear that the process of change has not ended. Like others, he is awaiting with interest the outcome of the next meeting of the Advisory Board for the Research Councils on 19 July at which a decision will be made about the future of the research counils. The motto seems to be that change is always good for them.

The change now in prospect is that foreshadowed by the report from Mr Richard Morris (see Nature 18 May, 1989) which, two months ago, came to the conclusion that the simplest way of reconciling frontier disputes between the research councils (the Medical Research Council and the Science and Engineering Research Council have made contentious ground of biotechnology, for example) would be to amalgamate them. Surprisingly, the research councils seem cheerful at the prospect. Only the MRC, pleading its tradition of independence and the distinctiveness of clinical research, threatens recalcitrance. But the only serious objection to this proposal is that it amounts to yet another administrative change in the organization of British civil science after a decade in which there has been more change than people's morale has been able to sustain. Members of the European academy must be aware of the dangers of further upheaval.

The case for biting Mr Morris's bullet is strong, even irresistable; the question for Mr Baker (who would have to approve and then legislate for radical change) is whether the proposed amalgamation of the four research councils concerned with the natural sciences (agriculture and the natural environment as well as those already named) as well as the Economic and Social Research Council would adequately meet the still crying needs in the mechanism for supporting British research. If lumped together and then endowed with the proposed transfer of up to $£ 70$ million a year from the universities' budget (to pay for overhead costs), the system would be spending more than $£ 900$ million a year. Mr Baker made a great deal, on Monday, of the need to get rid of paperwork in the application for research grants, but that is not the most serious obstacle now standing between researchers and the bench.

Two issues stand out, of which the most important is what appears to be the incorrigible inclination of the research councils as they are to spend the bulk of their funds on their own establishments. In agriculture, medicine and the natural environment, the explanation is historical - that is largely how their research programmes began in the half-century preceeding the upheavals of the early 1960s. The SERC, for the same or apparently equally good reasons (the economical provision of central services for its university constituents), has acquired the large Rutherford-Appleton Laboratory, two national observatories (one in Scotland) and a synchrotron radiation laboratory. There is nothing wrong with these establishments, which command the loyalty of those who work in them and which collectively are the source of much excellent work, but administratively they are a fixed cost and thus an obstacle to flexibility. Thus one crucial question to ask about the new super-research council is whether it would be managed in a decisely different way. Mr Baker should listen hard, in the next few weeks, for noises to that effect.

The other criterion by which the proposal for amalgamation should be judged is that of whether it would assist the international collaboration whose need is ever more urgent. Mr Baker said all the right things on Monday about the difficulties of small countries such as Britain when faced with the temptation to "do everything at once". The imaginative way out of this cleft stick would be to give the amalgamated council an international dimension, allowing it to make deals off its own bat (and not through the government that supports it) with likeminded organizations elsewhere, especially in Europe. In that respect, of course, Mr Baker will not be entirely dependent on the Advisory Board for advice. There is much that he could do himself to nudge the new pattern in a beneficent direction. But on past form, there will have to be a lot of nudging. 